\title{
Renaissance Historiography and Novel Anthropology in Pierre-Daniel Huet's «De l'Origine des romans» (1660)
}

\section{Rebecca Wilkin}

\section{(2) OpenEdition}

Journals

Electronic version

URL: http://journals.openedition.org/studifrancesi/27023

DOI: 10.4000/studifrancesi.27023

ISSN: 2421-5856

Publisher

Rosenberg \& Sellier

\section{Printed version}

Date of publication: 31 December 2006

Number of pages: 466-477

ISSN: 0039-2944

\section{Electronic reference}

Rebecca Wilkin, « Renaissance Historiography and Novel Anthropology in Pierre-Daniel Huet's «De I'Origine des romans» (1660) », Studi Francesi [Online], 150 (L | III) | 2006, Online since 30 November 2015, connection on 08 November 2020. URL : http://journals.openedition.org/studifrancesi/27023 DOI : https://doi.org/10.4000/studifrancesi.27023

\section{(c)}

Studi Francesi è distribuita con Licenza Creative Commons Attribuzione - Non commerciale - Non opere derivate 4.0 Internazionale. 


\section{Renaissance Historiography and Novel Anthropology in Pierre-Daniel Huet's "De l'Origine des romans» (1660)*}

Scholars have long recognized Pierre-Daniel Huet's (1630-1721) Traité de l'Origine des romans $(1670)^{1}$ as a defensive piece in a polemic about the novel that preoccupied French moralists, salonnières, and academicians throughout the seventeenth century. Jean-Pierre Camus (1582-1652), the bishop of Bellay who confirmed Huet in 1638, singled out «cet horrible pile d'Amadis» hailing from France's rival across the Pyrénées, as «la Mère source, et comme le cheval de Troye de tous les romans» ${ }^{2}$. The man whom Huet would later designate as «le prince des poètes médisants» ${ }^{3}$, Nicolas Boileau-Despréaux (1636-1711), expressed his wish that the effeminate heros of Madeleine de Scudéry's (1607-1701) voluminous novels - Le Grand Cyrus (1649-1653) and Clélie (1654-1660) - be plunged into the river Lethe ${ }^{4}$. By the 1660s, the novel was in dire need of a knight in shining armor, and no one was better poised than Huet to defend Scudéry against the caustic charges of that formidable «Satirique» ${ }^{5}$. In addition to numbering among Scudéry's friends and collaborating with Madame de Lafayette (1634-1693) in the production of Zayde, the novel to which De l'Origine des romans was bound in its initial publication, ${ }^{6}$ Huet had authored a two-volume novel of his own at the verdant age of twenty-five ${ }^{7}$. Unlike most writers of novels, however, and especially in contrast to the women with whom he consorted and collaborated, Huet boasted a vast store of historical knowledge. «Un des plus savants hommes de notre siècle», or at the very least «celui qui a le plus étudié» ${ }^{8}$, Huet galantly defended Scudéry's craft through a feat of erudition. Henri Coulet contends that Huet gave the novel its «lettres de noblesse» to rival those of tragedy or the epic'; Joan DeJean states that De l'Origine des romans was a «search for a genealogy and a pedigree for the fledgling French novel» ${ }^{10}$; Maurice Laugaa claims that the treatise represents «une tentative pour ancrer le roman dans un lointain passé, et lui assurer ses quartiers de noblesse» ${ }^{11}$.

It is precisely because of the historical framework deployed in De l'Origine des romans that other scholars regard the treatise not as a defense of the novel, but as an apologia for history. History - to borrow Paul Hazard's famous quip - «fit faillite» ${ }^{12}$

\footnotetext{
* I would like to thank Eric MacPhail for his pertinent bibliographic suggestions and David Wilkin for his helpful comments on a draft of this essay.

(1) The edition to which I refer in what follows is Hutet, De l'Origine des romans, ed. Fabienne Gégou, Paris, Nizet, 1971.

(2) Cited in H. Coulet, Le Roman jusqu'à la Révolution, Paris, A. Colin, 1967, vol. I, p. 30.

(3) Huet, Mémoires, ed. Philippe-Joseph Salazar, Paris, Klincksieck, 1993, p. 133

(4) Boileau, Les Héros de romans, dans Euvres complètes, Paris, Gallimard, 1969, 2 vols, t. 2., p. 208.

(5) Huet, Mémoires, op. cit., p. 133.

(6) On this textual «marriage», see F. BEAsLey, Un Mariage critique: "Zayde" et "De l'Origine des romans", «XVIIe siècle», 181, 1993, pp. 687-704.
}

(7) Diane de Castro, published posthumously in
1728 , juxtaposes the themes and conventions of the sentimental novel with the black legend of colonial Peru: a virtuous female protagonist, pursued by that tyrannical conquistador, Francisco Pizarro, reunites in the end with her long-lost paramour, disguised as the brother of her Incan lady in waiting.

(8) Cited in Sainte-Beuve, Causeries du lundi, Paris, Garnier, 1856, vol. II, p. 170.

(9) H. Coulet, op. cit. vol. I, p. 182.

(10) J. Dejean, Tender Geographies: Women and the Origins of the Novel in France, New York, Columbia U. P., 1991, p. 170.

(11) M. LaugaA, Lectures de Mme de Lafayette, Paris, A. Colin, 1971, p. 14.

(12) P. Hazard, La crise de la conscience européenne, Paris, Fayard, 1961, p. 27. 
under the Bourbon kings. Henri IV legislated a generalized amnesia following the wars of religion, which should be regarded «comme de chose non advenue» according to the Edict of Nantes. «[D]'en renouveller la mémoire» ${ }^{13}$ after 1598 was henceforth to be guilty of sedition. In the 1620s and 30s, the architects of the New Science spearheaded an attack on history; forgetting the past was the first step in the search for truth ${ }^{14}$. Galileo Galilei dismissed istorici as «dottori di memoria»" ${ }^{15}$, while René Descartes warned against imitating the heroes of history books for fear of succumbing «[aux] extravagances des Paladins de nos romans» ${ }^{16}$. From the «Cartesian moment» of the 1640s through the foundation of the Académie des sciences in 1661, science trumped antiquarianism. Aristocrats and bourgeois, men and women, thronged to public lectures on astronomy, chemistry, and anatomy ${ }^{17}$, while the musty charters studied by Pierre DuPuy and Théodore Godefroy ${ }^{18}$, the coats of arms collected by Nicolas Peiresc ${ }^{19}$, and the numismatic researches of Charles DuCange ${ }^{20}$ escaped public acclaim and attention ${ }^{21}$.

The brand of history that did manage to retain a large readership, exemplified by François Eudes de Mézeray's massive Histoire de France depuis Faramond jusqu'à maintenant, hardly inspired confidence. Reedited six times between 1643 and $1712^{22}$, Mézeray's Histoire narrated the lives and exploits of France's kings. Mézeray reserved special attention for state secrets and intrigues, was not above alluding to the miraculous, and included portrait engravings forged well after the lifetime of their subjects, as his successor, Gabriel Daniel, indignantly pointed out ${ }^{23}$. In theory, historians compiled their histories from accounts of witnesses contemporary to the events described. But could one distinguish invented narrative any more than imagined portraits? Nouvelles historiques such as Lafayette's Princesse de Montpensier (1662) and Saint-Réal's Don Carlos (1672) seemed no less believable than Mézeray's Histoire. Assessing the state of letters at the fin-de-siècle, Pierre Bayle laments that «ce mélange de la vérité et de la fable [qui] se répand dans une infinité de Livres nouveaux...fait que l'on n'ose croire ce qui est au fond croiable» ${ }^{24}$.

Largely as a consequence of the novel's historical pretensions, therefore, history too found itself beleaguered with criticism. Once again, the scholarly Huet was equipped to play the part of the hero. The author of several anti-Cartesian manifes$\operatorname{tos}^{25}$, Huet despised the philosopher's indiscriminate (and in his opinion, presumptuous) rejection of centuries of learning. Marc Fumaroli views De l'Origine des romans as Huet's first anti-Cartesian tract, since in it, Huet charts the development of history at the same time as he outlines the genesis of the novel: «cet adversaire et de Descartes et du scepticisme radical publia en 1670 sa Lettre à Segrais sur l'Origine des romans

(13) Recueil des anciennes lois, eds. Isambert, Taillandier, Decrusy, Paris, Belin-Leprieur, 1829, vol. XV, pp. 172-73.

(14) P. Rossi, Il passato, la memoria, l'oblio. Sei saggi di storia delle idee, Bologna, Il Mulino, 1991, p. 162-66.

(15) Cited in P. Rossi, op. cit., p. 162.

(16) Descartes, Euvres complètes, eds. Charles Adam and Paul Tannery, Paris, J. Vrin, 1969, vol. VI, p. 7.

(17) L. Timmermans, Accès des femmes à la culture (1598-1715): Un débat d'idées de Saint François de Sales à la Marquise de Lambert, Paris, H. Champion, 1993, pp. 123-132.

(18) B. KRIEgel, L'Histoire à l'age classique, Paris, PUF, 1988, vol. II, p. 181.

(19) P. ArIÈs, Le Temps de l'histoire, Monaco, Rocher, 1954, p. 177.
(20) L. FEIGÈRE, Etude sur la vie et les ouvrages de Du Cange, Genève, Slatkine Reprints, 1971, pp. 24-25.

(21) On the decline of antiquarianism after the 1640s, see P. Miller, Peiresc's Europe: Learning and Virtue in Seventeenth-Century France, New Haven, Yale U. P., 2000.

(22) P. ARIÈs, op. cit., p. 137.

(23) O. Ranum, Artisans of Glory: Writers and Historical Thought in Seventeenth-Century France, Chapel Hill, U. of North Carolina P., 1980, p. 204; P. ARIÈs, op. cit., p. 183.

(24) Cited in G. MAY, L'Histoire a-t-elle engendré le roman? «Revue d'histoire littéraire de la France», 15, 1955, p. 160.

(25) Censura philosophiae cartesianae (1689), Nouveaux mémoires sur le cartésianisme (1692), and Faiblesse de l'esprit bumain (1724). 
...justement pour réfuter Descartes et le traité de La Mothe Le Vayer» ${ }^{26}$. In Fumaroli's reading of De l'Origine des romans, Huet quarantines the infectious novel and salvages history's credibility by situating in the remote past the generic differentiation between the novel and history. All the while, he impresses the authority of history upon the reader through a lavish display of learning. «The first systematic historical and critical treatment of the prose narrative in the history of criticism ${ }^{27}$, De l'Origine des romans remains to this day an authoritative source on the history of fiction.

A plea for the novel or a justification of history? I shall argue that De l'Origine des romans is at the same time both and neither, depending on how one reads the treatise $^{28}$. In what follows, I show that three storylines compete for the reader's attention in De l'Origine des romans. Analyzing them in turn, I argue that each one imparts a distinct meaning, such that the reader's interpretation of the treatise depends upon which narrative he or she privileges. Those scholars who describe De l'Origine des romans as a legitimating genealogy of the novel are most sensitive to the narrative of perfectibility which Huet gleaned from the Protestant historian Lancelot du Voisin de La Popelinière (1541-1608). Those who argue that Huet condemns the novel on the grounds that it leads to ignorance, on the other hand, respond to his evocation of cycles of civilization, a theory regarding the pattern of history which received its elaboration in France at the hands of the jurist Jean Bodin (1529-1596). And while the historiographical expertise that Huet displays through his appropriation of these Renaissance sources certainly corroborates the impression that De l'Origine des romans affirms the authority of history, a third narrative paradoxically challenges the status of De l'Origine des romans as a history. In an anthropological account of the novel's origins, Huet does not just undermine his contention that history and fiction have been distinct genres for centuries; he confirms Descartes's accusation that history inherently resembles fiction.

\section{La Popelinière and the perfect(ible) novel}

In Huet's estimation, no epoch could rival that of the humanists, whose herculean recovery of ancient civilization remained the bedrock for the intellectual exploits of his own era. «Je trouve enfin la même différence entre un Savant d'alors, $\&$ un Savant d'aujourd'hui», he opined as an old man, «qu'entre Cristofle Colomb découvrant le nouveau monde \& le maître d'un Paquebot, qui passe journellement de Calais à Douvre» ${ }^{29}$. Given Huet's contempt for his contemporaries' servile exploitation of the great discoveries of their Renaissance predecessors, it is not surprising that he turned directly to Renaissance historiography when tracing the novel's path from

(26) M. Fumaroli, Historiographie et épistémologie à l'époque classique, «Certitudes et incertitudes de l'histoire», ed. Gilbert Gadoffre, Paris: Puf, 1987, p. 93. La Mothe Le Vayer, in contrast to Descartes, was a skeptic, but the discrepancies between ancient and biblical history that he pinpoints in $D u$ peu de certitude qu'il y a dans l'bistoire (1668) were every bit as damning as Descartes's assimilation of history to fiction. Fumaroli seems to forget here that Huet shared Le Vayer's skeptical tendencies.

(27) A. Forcione, Cervantes, Aristotle, and the Persiles, Princeton: Princeton U. P., 1970, p. 51.

(28) H. WHITE emphasizes the importance of narrative in establishing historical meaning: "insofar as the historical narrative endows sets of real events with the kinds of meaning found otherwise only in myth and literature," he writes, we should regard "every historical narrative ... as allegorical, that is, as saying one thing and meaning another" (The Content of the Form: Narrative Discourse and Historical Representation, Baltimore, Johns Hopkins U. P., 1987, p. 45). White lends credence to Descartes's observation that history is inevitably tainted by the conventions and expectations surrounding other genres, notably fictional ones. Yet while Descartes consequently and categorically discounts history, White embraces history's formal resemblance to fiction.

(29) HuEt, Huetiana ou pensées diverses, Paris, J. Estienne, 1722, p. 21. 
ancient Egypt to seventeenth-century France. The unacknowledged historiographical intertext most evident in Huet's treatise is that of La Popelinière's Histoire des bistoires (1599), the first French treatise on historiography ${ }^{30}$. Published together with L'Idée de l'histoire accomplie, L'Histoire des histoires provides an aggressively linear view of history. Although La Popelinière's Histoire was published only once, Huet was evidently familiar with it, as he gleaned the parallel that forms the backbone of his narrative directly from the pages of L'Histoire des histoires (1599). La Popelinière held that since history's subject is the story of human society's march to perfection ${ }^{31}$, history too is perfectible. He drew parallels between humanity's evolution from barbarity to civility and the progressive distinction between history and fiction. It is Huet's adoption of La Popelinière's parallel narratives that has led many readers - both in Huet's time and now - to view De l'Origine des romans as an apology for the novel and for female authorship.

Huet borrowed the plot of his story, whose most important feature is the alleged split between true and false narratives, from La Popelinière. La Popelinière begins his «narré» with a «nouveau traicté de l'origine des lettres» in which he addresses the common origins of fiction and history. He outlines four stages of historiography in the traicté. The first, «semblable de substance entre tous les peuples anciens» (vol. I, p. 37), was «naturelle et grossiere...escloze d'un mouvement naturel des premiers hommes, presque ruraux et non civilisez» (vol. I, p. 31) to transmit remarkable exploits «de pere en fils, comme une hereditaire traditive qu'ils donnoient de main en main à leur postérité» (vol. I, p. 33). The second resulted when contact with other peoples caused primitive societies to «adoucir leurs humeurs, et peu a peu subtiliser leur naturel demy sauvage» (vol. I, p. 37). But «l'indiscret meslinge des choses humaines avec les divines: et les trop apparens mensonges de leurs inventions» tarnished the credibility of these written and versified histories, and «les mieux avisez» (vol. I, p. 47) invented a third form of historiography, a «discours enfilé continu et non coupé, pour [la] mieux autoriser, et luy donner plus de poids et gravité» (vol. I, p. 47). Although the resulting prose histories succeeded in separating «le fabuleux du veritable» (vol. I, p. 48), they recounted noteworthy events only «en gros et par accidens» (vol. II, p. 29), an indelicacy that the fourth and final generation of historiographers would redress. Combining chronology and philosophy (the science of causes), they deduced history «par [les] causes et progrez [des actions humaines]» (vol. II, p. 32), thus helping the reader to understand «les motifs, conseil, progrez, issues et evenemens du tout» (vol. II, p. 31). While La Popelinière attributes this last and most accomplished form of history to the ancient Greeks and Romans, he remains dissatisfied with the historiography of his time. He therefore presents «le dessein de l'histoire nouvelle des françois» appended to l'Histoire des Histoires as a «modelle» of what perfect history might look like (vol I, p. 18).

Following La Popelinière's «modelle», Huet yokes the development of history to the evolution of human society from barbarity to civility. Like La Popelinière, Huet views the generic separation of fact and fiction as the sign of civilization. Primitive societies recounted «[leurs] origines imaginaires» that he scorns as «histoires entièrement controuvées et dans le total et dans les parties, mais inventées seulement au défaut de la vérité» (p. 49). As peoples shed their barbarous ways, they began to distinguish between fact and fiction. At this point, however, Huet bifurcates from

(30) LA POPELINIÈre, L'Histoire des histoires; L'Idée de l'histoire accomplie (1599), ed. Ph. Desan, 2 vols., Paris, Fayard, 1989.

(31) G. HupperT, The Idea of Perfect History:
Historical Erudition and Historical Philosophy in Renaissance France, Urbana, U. of Illinois P., 1970, p. 10 . 
the «modelle». La Popelinière follows history after the separation of the genres, but Huet pursues the fictional strand. While history was purified of its fictional elements, fiction was established as a genre in its own right. The roman was born when semibarbarian stories in which truth and falsehood intermingled were transformed by «des historiens [qui] eurent la hardiesse d'en faire [des histoires] de purement supposées». Nevertheless, these initial novels retained impurities: «Tous ces ouvrages auxquels l'ignorance avait donné la naissance portaient des marques de leur origine et n'étaient qu'un amas de fictions grossièrement entassées les unes sur les autres, et bien éloignées de ce souverain degré d'art et d'élégance où les Français ont, depuis, porté les romans» (p. 138).

Huet's story of a development from barbarity to civility, from the conflation of fact and fiction to their distinction, comes straight from the four stages of historiography outlined by La Popelinière. But Huet writes from a different vantage point. For La Popelinière, history was poised on the edge of perfection at the end of the sixteenth century. For Huet, the final polish on novels would have to await the reign of Louis XIV. The unprecedented sophistication of the French novel results, according to Huet, from the unparalleled civility of French society: «nous devons cet avantage à la politesse de notre galanterie» (p. 139). Huet would thus appear to designate the seventeenth-century French novel as the most perfect point in an ever more perfect story, just as La Popelinière viewed history as ever more perfect as human society evolved. In effect, he celebrates the superiority of the French novel with respect to those of other nations - «leurs plus beaux romans égalent à peine les moindres des nôtres» - and praises Scudéry as «[cette] sage et vertueuse fille» responsible for elevating the novel to an unprecedented level of sophistication (p. 148).

Huet's recourse to La Popelinière's progressist view of history convinced at least some of his contemporaries that De l'Origine des romans amounted to a defense of the novel. Humorless «Catons», Huet recounts in his memoirs, complained that De l'Origine des romans displayed «[des] marques que je leur étois favorable [aux romans $\rangle_{\gg^{32}}$. One contemporary reader nonetheless noticed the regret tinging Huet's celebration of the French novel when he remarks that «notre nation [a] cédé aux autres le prix de la poésie épique et de l'histoire» (p. 139). Despite his praise for her, Scudéry wrote to Huet upon reading De l'Origine des romans to refute «l'accusation que vous faites aux romans bien faits, d'avoir amené l'ignorance à leur suite» ${ }^{33}$. It is clear from Scudéry's defense, in which she argues that novels lead their (female) authors to read history, that she seeks to attenuate a perceived rivalry between history and the novel. In her understanding, De l'Origine des romans treats the novel as an illegitimate usurper, and women novelists in particular as an endangerment to the Republic of letters ${ }^{34}$. Scudéry was probably not familiar with Huet's «modelle», L'Histoire des bistoires. She nonetheless understands that Huet does not forecast indefinite perfectibility for French civilization. And in effect, in his crucial discussion of the origins of European novels, Huet mobilizes the very conception of history that La Popelinière had intended to supercede with L'Histoire des histoires: the understanding of history as the story of the rise and fall of civilizations.

(32) Huet, Mémoires, op. cit., p. 100.

(33) SCUDÉRY, Scudéry: Sa vie et sa correspondance, eds. Rathery and Boutron, Paris, Techener, 1873 , p. 295.

(34) E. HARTH remarks that Huet "saw fiction as a substitute for history, lies to take the place of a missing truth" (Ideology and Culture in Seventeenth-Century France, Ithaca, Cornell U. P., 1983, p. 203). 


\section{Bodin and the end of history}

First developed in fifteenth-century Italy, the cyclical understanding of history was disseminated in France by Bodin in his Methodus ad facilem historiarium cognitionem (1566). ${ }^{35}$ The Methodus secured Bodin's reputation as a jurisconsult ten years before the publication of his Six Livres de la république (1576) and remained an authoritative work of historical theory until Montesquieu's time ${ }^{36}$. The Methodus purported to provide advice on how to select and read history, and its greatest discernable impact was on subsequent writers of history. La Popelinière's idea of perfectibility in fact comes from the Methodus. According to La Popelinière, Bodin denied that the exploits of the ancients remain inimitable. «Le temps qui s'est escoulé depuis [les anciens] jusques icy», he insists, «nous doit rendre superieurs en toutes choses» (II: 13). In choosing a linear narrative, La Popelinière nevertheless skirted a tension evident in Bodin's Methodus. In the Methodus, Bodin aimed to discredit the myth of the golden age and its implications for subsequent epochs - namely, perpetual decline. He hoped that understanding the causes of the decline of civilizations might make it possible to avert decline altogether. However, he replaced the notion of interminable decline with the idea of cycles of history. These imply repetition and are thus antithetical to the idea of perfectibility.

The assumption underlying the cyclical view of history is that man's inherent inconstancy results in foreseeable consequences. Distinguishing the arbitrary character of human history from the teleology of sacred history, Bodin insists that the causes and effects that constitute human history mirror the inconstancy of men. «l'histoire humaine découle principalement de la volonté des hommes qui n'est jamais semblable à elle-même et l'on n'entrevoit point son terme» (p. 282). Bodin describes human history as the study of «l'origine, la croissance, l'apogée, les changements et la fin des républiques» or «l'origine, l'équilibre, la corruption et la chute... de toutes les républiques» (p. 283). Despite the unpredictability of human behavior, «l'histoire humaine incertaine et confuse» therefore shows consistent patterns (p. 283). What goes up, must come down, such that one can «embrasser d'un coup d'œil l'évolution de chaque Etat» (p. 283-84). Similarly, Louis Le Roy, another late sixteenth century historiographer who reveals Bodin's influence, explains in De la vicissitude ou variété des choses en l'univers ... depuis le temps où a commencé la civilité E mémoire bumaine jusques à present (1575), that «tous affaires humains [sic], armes, lettres, langues, arts, estats, loix, mœurs ... ne cessent de hausser et abaisser, amendans ou empirans alternativment ${ }^{37}$.

De la vicissitude evinces the ethical component implicit in the cyclical view of history. Rather than privileging the present as an ameliorated continuation of the past, understanding history as the rise and fall of civilizations allowed for parallels to be made between different epochs. Thus in keeping with the Renaissance ideal of instruction by example - historia magistra vitae - one could draw lessons about the present - or indeed about the future - from past events. Not surprisingly, the fate of classical Rome loomed large for humanists so conscious of recovering long-lost treasures. In the closing lines of De La vicissitude, Le Roy's prose takes a visionary turn:

(35) J. Bodin, Méthode pour faciliter la connaissance de l'bistoire, «Euvres philosophiques de Jean Bodin», ed. and trans. Pierre Mesnard, Paris, P.U.F., 1951, pp. 271-475. On Bodin, see P. BuRKE, The Renaissance Sense of the Past, New York, St. Martin's P., 1969, p. 87 and D. Kelley, Foundations of Modern Historical Scholarship: Language,
Law, and History in the French Renaissance, New York, Columbia University Press, 1970.

(36) P. Mesnard, Vers un portrait de Jean Bodin, «CEuvres philosophiques de Jean Bodin», Paris, P.U.F., 1951, p. xvi.

(37) Le Roy, De la Vicissitude ou variété des choses en l'univers, Paris, Fayard, 1988, p. 426. 
Que si la memoire et cognoissance du passé est l'instruction du present, et advertissement de l'advenir, il est à craindre qu'estans parvenues à si grande excellence, la puissance, la sapience, disciplines, livres, industrie, ouvrages, cognoissance du monde: ne dechoient autrefois comme ont faict par le passé et aneantissent: succedant à l'ordre et perfection du jourd'huy confusion, à la civilité rudesse, au sçavoir ignorance, à l'élegance barbarie (p. 426-27).

Evoking the fate of the Roman empire, Le Roy imagines the destruction wrought by barbarians of all climes - Huns, Lombards, Sarrasins, Vandals, Goths - on European architecture, libraries, and morals. He goes on to predict warfare of the worst sort (civil), the profanation of religion, plague, famine, floods, and finally, original chaos. Writing in the midst of the wars of religion, Le Roy must have wondered if his countrymen were already treading down the slippery slope to anarchy.

Thanks to the peace which marked the beginning of Louis XIV's reign, anxieties regarding an imminent apocalypse had largely subsided by Huet's time. But the fear of decadence was alive and well. And as was the case for Renaissance historians, it was commonplace for any seventeenth-century admirer of the ancients to evoke the Middle Ages as a potential precedent ${ }^{38}$. We have seen that Huet reserved his greatest respect for the humanists who had rediscovered the ancients. Predictably, he insists on the destruction wreaked by «ce débordement de barbares qui sortirent du Septentrion [et qui] inonda toute l'Europe et la plongea dans de si profondes ténèbres qu'elle n'en est sortie que depuis environ deux siècles» (p. 133). As a result, European romans «n'ont point d'autre origine que les histoires remplies de faussetés qui furent faites dans des temps obscurs, pleins d'ignorance, où l'industrie et la curiosité manquaient pour découvrir la vérité des choses et l'art pour les écrire» (p. 172). The cultural oblivion caused by the barbarians precluded any possible influence from previous fictional forms, and Huet underscores the indigenous nature of European fiction: «Il n'y a donc pas lieu de contester que les romans français, allemands, et anglais et toutes les fables du Nord sont du cru du pays nées sur les lieux, et n'y ont point été apportées d'ailleurs» (p. 172). Thanks to the leveling of learning that occurred in medieval times, according to Huet, the French novel can boast a distinct origin that reinforces its contemporary difference (and superiority) with respect to the fiction produced by other nations.

Huet therefore characterizes the Middle Ages as a rupture in the history of fiction, and more generally, as a caesura in history. In Huet's account of the origin of European novels, the Middle Ages witnessed the demise of one civilization and the beginning of another. Huet thus interrupts the linear narrative of perfectibility and produces two separate histories, each with its own beginning and end. This scission of the singular, linear narrative into two introduces the possibility of cycles, with the corresponding ethic of comparison. Heliodorus' Theogenes and Chariklea (ca. 400 A.D.) is the highpoint of pre-medieval fiction to which the novel is once again rising, thanks to French authors such as Honoré d'Urfé and Madeleine de Scudéry (p. 77).

Likewise, the cyclical form of history invites the reader to anticipate the downturn that inevitably follows a civilization's zenith. Le Roy had projected that the catalyst for decline would come from the outside, wreaked by strangers in shape, color, and dress, as it had for ancient Rome. By contrast, Huet intimates that France is threatened internally by her own subjects. Despite his admission that France's superior civility is owing unto «la grande liberté dans laquelle les hommes vivent avec les femmes», women's participation in the Republic of Letters has eroded the dis-

(38) N. Edelman, Attitudes of Seventeenth-Century France towards the Middle Ages, New York, 
tinction between fact and fiction that, in Huet's view, is the foundation of a civilized society (p. 139). Huet blames the prominence of women in France's literary debates as the cause of a reversal wherein fiction, rather than history, constitutes the source of society's knowledge.

Les dames ont été les premières prises à cet appât: elles ont fait toute leur étude des romans et ont tellement méprisé celle de l'ancienne fable et de l'Histoire, qu'elles n'ont plus entendu ces ouvrages qui tiraient de là autrefois leur plus grand ornement. Pour ne rougir plus de cette ignorance dont elles avaient si souvent occasion de s'apercevoir, elles ont trouvé que c'était plutôt fait de désapprouver ce qu'elles ignoraient que de l'apprendre, sans se souvenir de ces trois illustres Marguerite et de tant d'autres dames qui ont honoré la France et l'Italie par leur savoir. Les hommes ont suivi l'exemple des femmes pour leur plaire; ils ont condamné ce qu'elles condamnaient et appelé pédanterie ce qui faisait une partie essentielle de la politesse encore du temps de Malherbe (p. 140).

During the Renaissance, women such as François I's sister, Marguerite d'Angoulème, reine de Navarre (1492-1549), her niece, Marguerite de France, duchesse de Savoie (1523-1574), and the turbulent «reine Margot» (1552-1615) ${ }^{39}$, modeled their learning on that of male scholars. By contrast, Huet insists, in seventeenth-century France men imitate women. «Studying» novels rather than history, men captivate women by complying with the deliberate impoverishment of the Republic of Letters.

Neither La Popelinière, nor Bodin, whose misogyny welled over in De la démonomanie (1580), nor even Le Roy, who specifically warns against imminent decadence, had ascribed a role to women in the decline of civilizations. Huet however melded two Renaissance conceptions of the passage of time to address a preeminently contemporary concern: women's place in the res publica litteraria. Since De l'Origine des romans comprises competing narratives featuring indefinite perfectibility or repetitious cycles, it can be read either as a gallant apology of the novel and of female authorship, or as their condemnation, either as the work of a closet modern, or as the manifesto of a disgruntled ancient. The sophistication of narrative fiction and the preeminence of women in society may signal that society's attainment of its cultural potential. But when novels supercede history, and when women usurp the place of those men who had gallantly invited them into Parnassus, the result is a return to origins: «Ainsi une bonne cause a produit un très mauvais effet et la beauté de nos romans a attiré le mépris des belles-lettres, et comme l'ignorance les avait fait naître, ils ont aussi fait renaître l'ignorance» (140, emphasis mine). A hybrid of La Popelinière's four stages of historiography and Bodin's «histoire humaine et incertaine et confuse», De l'Origine des romans delivers a mixed message: the French novel represents the apotheosis of civility, but spells the apocalypse of civilization, for the primacy of fiction over history heralds a return to original ignorance.

\section{Novel anthropology}

With a storyline that either charted indefinite progress or predicted the fall of civilization, Huet remained firmly within historiographical conventions ${ }^{40}$. Yet

(39) All of these women knew other languages. The author of L'Heptaméron spoke Spanish, Italian, and learned Hebrew. Marguerite de Savoie knew Greek and Latin; she supported poets including Ronsard and Du Bellay and attracted a number of prominent jurisconsults to the university of Turin. Henri II's daughter and wife of Henri IV is famed for having improvised a response in Latin to a visiting bishop who addressed her in Latin. 
in addition to the recognizably historical themes of progress and decadence that structure his narrative, Huet elaborates an anthropological explanation of the novel's origin whose traits are difficult to reconcile with those of history. Contrary to La Popelinière, who insists that bistoires (including stories and history) are the product of culture ${ }^{41}$, Huet insists that fiction is natural. «Il faut chercher leur première origine dans la nature de l'esprit de l'homme inventif, amateur de nouveautés et des fictions, désireux d'apprendre et de communiquer ce qu'il a inventé et ce qu'il a appris» (p. 51). Huet also rejects Aristotle's definition of art as imitation when he denies that fiction results from nurture ${ }^{42}$. «Cette inclination aux fables, qui est commune à tous les hommes, ne leur vient pas par raisonnement, par imitation ou par coutume; elle leur est naturelle et a son amorce dans la disposition même de leur esprit» (p. 130). Further, the attraction to fiction «est particulier à l'homme et ne le distingue pas moins des autres animaux que sa raison», Huet writes in a covert refutation against Descartes's proclamation of the ubiquity of bon sens (p. 130). Humans' innate love for fiction flattens differences between the barbarous and the civilized, over time and through space: «les nations les plus barbares aiment les inventions romanesques comme les aiment les plus polies» (p. 128).

Contrary to the widespread view that De l'Origine des romans provides a genealogy of the novel, it seems that what so fascinated Huet about the novel was precisely its defiance of genealogy ${ }^{43}$. History, according to Huet's La-Popelinière-esque storyline, depends on the continuity of memory from one generation to the next and builds on itself cumulatively. Fiction, by contrast, emerges independently and locally, spontaneously generating in the minds of unconnected individuals. While history's transmission «de père en fils» accompanies the patrilinear bloodline ${ }^{44}$, the French

(40) Huet's integrity as a historian is reinforced by the many pages he devotes to deliberating about what is true and what is false in the history of fiction. In his in-depth analysis of a narrative entitled Du vrai et parfait amour, also known as Théogène et Chariclée, he draws on his expertise as a philologist as well as his familiarity with architectural history to determine that its attribution to the second century Christian philosopher, Athenagoras, is apocryphal. Huet contends that the gullible translator of the work, Martin Fumée, was presented with the manuscript as a prank, and he was fooled not once, but twice. In addition to believing the work to be by Athenagoras, he also supposed it to be a history when it is in fact, a novel: "il le prend enfin pour une véritable histoire, faute d'intelligence en l'art des romans" (De l'Origine des romans, p. 86). While Fumée's mistake confirms Descartes's devastating observation of history's resemblance to fiction, Huet's exposure of the prank suggests that confusion between the genres originates in the eye of the beholder. If Fumée - or for that matter, Descartes - couldn't tell the difference between history and novels, it was his own fault.

(41) La POPELINIÈRE denies that fiction is natural when he refutes the claim that the world is eternal: "Car si elles estoyent eternelles, elles seroyent naturelles, ... et par ainsi general et ordinaire à tous les peuples, comme ...les instincts de la nature, sont generaux, communs et immuables" (vol I., pp. 25-26)

(42) Here is what ARISTOTLE says about imitation in the Poetics: "the impulse to imitate is inherent in man from his childhood; ....everyone's enjoyment of imitation is also inborn... The making of epics and of tragedies ....all have this in common, that they are imitations" (On the Art of Fiction, trans. L. J. Potts, Cambridge, Cambridge U.P., 1968. pp. 20-21).

(43) As Sainte-Beuve noted, Huet "geometrically" refuted the principle of genealogy in Huetiana (p. 164). HuEt in effect ridicules men's desire to perpetuate "leur nom après leur mort" (Huetiana, op. cit., p. 328). Because paternity implies the relation of two terms, when one of the terms is destroyed, Huet argues, so too is the relation; thus when a father dies, his son is not only fatherless; his filial status is annulled (Huetiana, op. cit., p. 335). This was an unusual stance to strike at a time when even robins were commissioning family histories like never before (J. SMITH, The Culture of Merit: Nobility, Royal Service, and the Making of Absolute Monarcby in France 1600-1789, Ann Arbor, U. of Michigan P., 1996, pp. 78-90). To be sure, Huet had little to gain personally from genealogy; like Scudéry, he was of bourgeois stock and was orphaned at the age of six. "Sapho n'avoit que six ans lorsque ses parens moururent," reads Scudéry's self-portrait in Artamène, "ses parens laisserent Sapho avec un bien beaucoup au-dessous de son merite" (cited in G. MongréDIEN, Les Précieux et les précieuses, Paris, Mercure de France, 1963, p. 123). Likewise, Huet's father, Daniel Huet, died in 1633, and his mother, Isabelle Pillon de Bertoville, passed away three years later: "Je la perdis à l'âge de six ans ...je n'ai jamais senti une si longue \& si vive douleur" (Huetiana, op. cit., p. 320).

(44) La Popelinière, op. cit., vol. I, p. 33. 
novel has no ancestors and, if Bodin's cyclical narrative prevails over La Popelinière's progressive narrative, it will have no heirs. The paradoxical result is that De l'Origine des romans traces the history of a genre that needs no history. Indeed, if fiction flourishes when the continuous transmission of history is interrupted, why bother accounting for the novel from ancient Egypt to seventeenth-century France by means of the «narration continue» that is history ${ }^{45}$ ? Huet himself underscores the superfluity of history when he addresses the source of European novels. «Puisqu'il est donc vrai que l'ignorance et la grossièreté sont les grandes sources du mensonge», he reasons, «n'est-il pas bien vraisemblable que cette ignorance produisit dans l'Europe le même effet qu'elle a toujours produit partout ailleurs? Et n'est-ce pas en vain que l'on cherche dans le hasard ce que nous trouvons dans la nature?» (p. 133). Curiously, at the same time as Huet grants the novel a history, his anthropological story of origins emphasizes the novel's irreducibility to history. He defines the novel on history's terms in his La-Popelinière-esque story of the ever more perfect novel. In his anthropological account, conversely, he emphasizes fiction's a-historicity. On the one hand, he reinforces history's authority by designating it as the legitimating discourse. On the other hand, he denies that authority when he places the origins of fiction entirely outside of history's ken. Paradoxically, then, De l'Origine des romans both confirms and negates a generic hierarchy that situates the novel in the shadow of history.

If Huet's anthropological account of the novel's origins is unexpected in a work of history, his choice of vocabulary is even more surprising. Preferring the plausible effects of human nature - «n'est-il pas bien vraisemblable que cette ignorance produisit dans l'Europe le même effet qu'elle a toujours produit partout ailleurs?» - to the vain chronicling of chance - «Et n'est-ce pas en vain que l'on cherche dans le hasard ce que nous trouvons dans la nature?»-Huet crosses generic lines and presses into the service of history the standard arguments with which novelists justified fiction. ${ }^{46}$ Novels, Scudéry insists, must not only be «plus [beaux] que la vérité, mais encore plus vray-semblable[s]» ${ }^{47}$. In keeping with the moral imperative of showing virtue rewarded and vice punished ${ }^{48}$, vraisemblance combined a normative concern for social acceptability with the rationalist requirement of a plot constructed around cause and effect. In practice, historians embellished and improved upon the facts in order to meet their contemporaries' expectations. Yet they could not stake aesthetic claims on such manipulations, since history remained - in theory, at least - the province of truth. In order to valorize the novel, therefore, Scudéry intimates that history is an artless craft, for the historian must dutifully report what happened, however random the facts, however incredible the truth. In contrast, the novel's departure from historical fact evinces the author's taste and skill. The novel's vraisemblance marks its aesthetic superiority to history, «car enfin», Scudéry reasons, «il est permis au hazard de faire des choses incroyables ${ }^{49}$.

(45) Seventeenth-century historiographers typically defined history as "une narration continue, qui a ses parties jointes \& liées" (LE Moyne, De l'histoire, Paris, L. Billaine, 1670, pp. 77-78).

(46) Through vraisemblance, novelists sought to legitimate their works by demonstrating their conformity to the guidelines for other genres laid out in Aristotle's Poetics. The Poetics had been widely edited and commented by the Italians in the sixteenth century, although the first French edition appeared only in 1671 (R. BRAY, La Formation de la Doctrine Classique en France, Paris, Nizet, 1966, p. 49). The abbé D'Aubignac, whose Pratique du théatre (1657) made the content of Aristotle's Poetics widely available to the non-lettered French public, affirms, "la Vraisemblance est ... l'essence du Poëme Dramatique, \& sans laquelle il ne se peut rien faire ni rien dire de raisonnable sur la Scène" (La Pratique du théatre, Paris, Champion, 1927, p. 65).

(47) SCUDÉRY, Les Conversations sur divers sujets, Amsterdam, D. du Fresne, 1682, p. 34.

(48) HuEt, De L'Origine des romans, op. cit., p. 47.

(49) SCUDÉRY, Les Conversations, op. cit., p. 37. 
Since vraisemblance is what ostensibly distinguishes the novel from history, Huet's substitution of vraisemblance for the fastidious work of genealogy corroborates Descartes's claim that «mesme les histoires les plus fideles» omit, idealize, and therefore end up resembling novels ${ }^{50}$. In a jab at the scholastic philosophy he despised, Descartes equated vraisemblance with duplicity: «la Philosophie donne moyen de parler vraysemblablement de toutes choses \& se faire admirer des moins sçavans ${ }^{51}$. Descartes conflates artfulness and artifice; he collapses Scudéry's aesthetic distinction between the prosaic truth and artful vraisemblance into a moral opposition between truth and lies. Vraisemblable appears to be true, and therefore must be false, since appearances are consistently misleading. From a Cartesian perspective, when Huet rejects chance in favor of vraisemblance, he is imitating the very gesture that founded the European novel: he is making up one of those «[origines imaginaires] inventées à défaut de la vérité» (p. 49).

On balance, De l'Origine des romans is a resolutely ambivalent work. It conjugates a linear narrative of infinite perfectibility with a cyclical story of the rise and fall of civilizations. It flatters women authors, but hints at the danger of the influence they wield. It assigns two incommensurable origins - the distant past and human nature - to the novel. It poses as an example of unimpeachable history all the while deploying conventions that supposedly distinguish novels from history. The multiple interpretations authorized by De l'Origine des romans no doubt contributed to Huet's obscurity. He would go down in literary history as a well-meaning, but befuddled érudit - a sort of lingering leftover of the Renaissance and its «[savoir] pléthorique et absolument pauvre» ${ }^{52}$. «Huet», wrote that prolix second empire commentator, Charles Augustin Sainte-Beuve (1804-1869), «représente et prolonge ...le mouvement de la Renaissance»; he was «le dernier de cette forte race des savants $\mathrm{du} 15^{\mathrm{e}}$ et du $16^{\mathrm{e}}$ siècle»» ${ }^{53}$. And a century later, Hazard delighted in recounting how Huet's house crumbled under the weight of his library; the anecdote epitomized a man whose gargantuan erudition blinded him to its effects ${ }^{54}$.

Nevertheless, Huet's posthumous reputation says more about the triumph of Cartesianism and its intolerance for ambiguity than it does about Huet. In De l'Origine des romans at least, Huet probed the questions that preoccupied his contemporaries more deeply than many of them dared to do. When it came to the idea of history and the attendant issue of women's place in it, for instance, Huet revealed that the moderns and the ancients battled one another from two sides of one coin. All it took was a slight twist for the rising wheel to tip downward, and a dose of misogyny to transform paragons of progress into stultifying harpies. At the same time, Huet countered a narrowing understanding of history with the very tactics that in Descartes's view discredited history altogether. As the novel gained prominence, history was construed in opposition to fiction, with the result that facticity emerged as history's defining feature and primary merit. Indeed, while Renaissance humanists upheld history as a lesson on how to live one's life, Scudéry defines history as a chronological repertory of chance events. Without an organic moral purpose to bind them together,

(50) Descartes, op. cit., vol. VI, p. 7.

(51) Ibid., p. 6.

(52) M. Foucault, Les Mots et les choses. Une archéologie des sciences bumaines, Paris, Gallimard, 1966 , p. 45.

(53) Sainte-Beuve, Causeries du lundi, Paris, Garnier, 1856, pp. 179, 164.

(54) P. HazArD, op. cit., vol. I., p. 40. In the Demonstratio evangelica (1672), Huet attempted to show that pagan theology - from the Egyptians to the Gauls and Romans - derived from the words or deeds of Moses, without realizing that the evidence he mustered could just as easily - and more convincingly - lead its reader to the opposite conclusion. Louis XIV's gallican theologian, Jacques Bénigne Bossuet (1627-1704), and the Jansenist Antoine Arnauld (1612-1694) both considered Huet's Christian manifesto as a potentially subversive work. 
however, facts form a fragmentary foundation for a discipline. Huet resists this paltry view of historical truth in De l'Origine des romans. By considering what might appear vraisemblable to his reader, he recovers the narrative coherence that is lost when history abandons its moral prerogatives to the novel out of fear of resembling its rival. Above all, Huet's supplementary tale of the novel's origins in human nature exemplifies the conviction that truth is after all irreducible to facts.

Unfortunately, Huet's clairvoyance diminished as the irenicism of the beginning of Louis XIV's reign gave way to a climate of militancy. Just a quarter of a century after the publication of De l'Origine des romans, the infamous Querelle des anciens et des modernes polarized the republic of letters into two equally impoverished camps ${ }^{55}$. While the moderns' La-Popelinière-esque arguments for progress displayed a singular lack of innovation ${ }^{56}$, the ancients' vituperations against contemporary society revealed their amnesia of the great historiographical innovations of the Renaissance. Striking a bellicose pose, Huet responded to the moderns' vindication of progress by resuscitating the moribund theory of decline that Bodin had dismissed over a century earlier. «Les terres nouvellement cultivées, » he reasons in his « Défense des anciens contre les modernes» (1722), «sont beaucoup plus vigoureuses, \& plus fécondes que des terres lassées \& épuisées par un longue culture» ${ }^{57}$. The huge bunches of grapes reported in the time of Moses have disappeared from the Old World, while one can see «des raves \& des melons ...qui faisoient la charge d'une charrette» in the New World $^{58}$. Like the fruits of the earth, men too are becoming smaller and losing vigor. All told, the geniuses of ancient Greece and Italy, Huet insists, «étoient supérieurs aux nôtres» ${ }^{59}$. Huet's colorful mix of biblical and secular history, together with his uncritical acceptance of testimonies from long ago or far away, jarred with the public's increasing demand for vraisemblance in matters historical, a demand that he had once upon a time honored. Amidst the sterile antagonism of the Querelle, the balance that Huet negotiated in De l'Origine des romans appears as fragile as it does fertile. Indeed, if Huet's authorial trajectory from gallant novelist, to sagacious historian, to entrenched polemicist may be taken as a model of historical change, then it seems evident that the erosion he deplored was not caused by barbarians, novels, nor even by women. Ideological intransigence was the culprit.

REBECCA WILKIN

(55) B. KRIEGEL calls the Querelle the "nadir" of seventeenth century historiography (op. cit., p. 271).

(56) The moderns repeatedly construed the passage of time as the accumulation of the new on top of the old, in a way that was antithetical to the fresh start vindicated by the New Science, and especially by Descartes, who served as a sort of mascot for their cause. In his Traité pour juger des poëtes grecs, latins et français (1670), Desmarets de Saint Sorlin upholds the perfectibility of man's works on the grounds that each generation's accomplishments accrue to the next. "Les ouvrages des hommes ...ont commencé par être imparfaits, et se sont perfectionnés peu à peu. ... [les hommes] se corrigent les uns sur les autres, et les derniers sont les les plus heureux, les mieux instruits et les plus parfaits" (cited in H. Rigault, Histoire de la Querelle des anciens et des modernes, Paris, Hachette, 1856, p. 106). See also H. BARON, The Querelle of the Ancients and Moderns as a Problem for Renaissance Scholarship, «Journal of the History of Ideas», 20, 1959, 3-32.

(57) Huet, Huetiana, op. cit. p. 30.

(58) Ibid., p. 30-31.

(59) Ibid., p. 32. 